\title{
Variation Characteristics of Building Height Types in the Vertical Urban Expansion Process
}

\author{
Peifeng Zhang*, Zheng Cheng, Jianfeng Xu, Yun Dai, Xiaolin Qi, Ruigang Chen, \\ Xin Li, Neng Zhang, Zuolong Li \\ College of Pipeline and Civil Engineering, China University of Petroleum, Qingdao, Shandong,266580, China
}

Received: 5 March 2021

Accepted: 2 July 2021

\begin{abstract}
The evolution of building height types in three-dimensional (3D) space is important for urban planning and urban atmospheric environment. This paper used the data of buildings' 3D information which were extracted from high resolution satellite images (QuickBird) in Qingdao city from 2003 to 2012 based on ArcGIS to detect the spatio-temporal variation characteristic of building height types in the urban renewal process in China. The results indicated that mid-rise and mid-high-rise buildings were the main architectural landscape components, the buildings grown in vertical direction. Main roads, business districts and schools had a significant effect on the spatial layout of building height types within $700 \mathrm{~m}, 1800 \mathrm{~m}$ and $1000 \mathrm{~m}$ from them, respectively. The closer to these infrastructures, the more mid-high-rise, high-rise and ultra-high-rise buildings were distributed, and this phenomenon was highlighted during the urban renewal process. The dominant topography for all buildings was the area below $60 \mathrm{~m}$ of elevation and less than $5^{\circ}$ of slope. And buildings decreased rapidly with the increasing elevation and slope. These findings are important for understanding the characteristics of architectural landscape, simulating the evolution of urban architectural landscape and researching the urban atmospheric environment.
\end{abstract}

Keywords: three-dimensional architectural landscape, variation, building height types, infrastructure, terrain

\section{Introduction}

The changes to the urban architectural landscape have caused much concern in terms of urban design, planning and management. Most research on the spatio-temporal characteristics of the urban landscape focused on the horizontal expansion that has occurred.

*e-mail: windzpf@163.com

Many papers have concentrated on spatio-temporal dynamics and drivers of urban area growth [1-3], the urban expansion rate [4] and urban land use intensity [5], based on remote sense data [6-7], nighttime stable light data [8] and government statistics [9]. Researchers analyzed the influence of main roads, business districts, schools and terrain on urban landscapes, and found that road networks reflected the morphological and structural characteristics of cities [10], roads were a strong attractor of urban expansion [11, 12] and landscape patterns [13]. Lower road density reduced the land 
surface temperature [14] and urban landscape showed variable sensitivity to roads types. Urban growth density [15], urbanization landscapes fragmentation [16] and urban land changes [17] decreased with distance from roads and schools. The distance to the central business district (CBD) had the greatest influence on housing prices [18], followed by distance to schools and roads [19]. Terrain affected the dynamic characteristics of the urban landscape pattern $[20,21]$ and urban distribution $[22,23]$. Built-up areas were mainly distributed in lower slope $[24,25]$ and low-altitude areas.

Every city exhibits both horizontal and vertical urban expansion concurrently. Megacities all tended to horizontally expand initially and then grow vertically in the already developed areas. Vertical expansion is one of the mainly modes of urban expansion with increasing building height [26] and floor area ratio [27-29] in cities. Which resulted in markedly change of urban architectural landscape and urban environment. There are few studies on the spatio-temporal characteristics of both changes in building height types and their distribution around main infrastructures and terrain in three-dimensional (3D) space during the urban renewal process.

The urban internal infill development of increasing the building height and floor area ratio is the mainly feature of urbanization process under the influence of urban planning and development policy, land price and urban social economic development system in China. The spatial distribution characteristics of building height types have a certain relationship with the distance of urban infrastructure and terrain. So, we will analyze the spatio-temporal evolution characteristics of building height types in the process of urban vertical expansion in Qingdao City, based on buildings' 3D information extracted from high resolution satellite images (QuickBird) mainly using spatial analysis of ArcGIS. They will provide important guidance for urban planning, ecological city construction and urban atmospheric environment, etc. There were there major goals for this study: (1) analyze the evolution features of building height types (2) detect the spatio-temporal characteristics of building height types with distance from main roads, business districts and schools (3) find the selective of buildings to terrain in the process of urban vertical growth.

\section{Materials and Methods}

\section{Study Area}

Shinan and Shibei districts are rapidly developing areas in Qingdao City, Shandong, China, with a total area of $58.64 \mathrm{~km}^{2}$ [30] (Fig. 1). It is composed of mountains, hills, coastal lowlands and plains. Fushan Mountain is the highest with elevation of $384 \mathrm{~m}$. The area below $60 \mathrm{~m}$ and above $100 \mathrm{~m}$ accounts for $86.8 \%$ and $3.1 \%$ of the total area, respectively. Plain and shelving area account for $84 \%$ of the total area, while abrupt slope area account for $1.2 \%$. They have experienced significant changes in both industrial structure and architectural landscapes resulting from socioeconomic development and urban renewal policy between 2003 and 2012.

Shinan District is the center of administration, tourism, culture, trade, finance and technology in Qingdao, and had a total population of 0.55 million and GDP of 71 billion RMB in 2012 [31]. Hong Kong Middle Road and Zhongshan Road business district are the eastern commercial district and western business center, respectively, in Qingdao City. The Shibei District is an important industrial and commercial area of Qingdao City, and most ports and trade activities are located on the west coast. It has experienced strong economic growth with a GDP of 50 billion RMB in 2012[31]. The CBD of Qingdao City and the Taidong Road business district are located in the east and west part of Shibei District [32], respectively. The architectural landscape, especially the building height, building coverage ratio, floor area ratio and building function, changed dramatically in Shinan and Shibei district between 2003 and 2012.

\section{Technical Framework}

We attained the basic data by extracting buildings' 3D information from high resolution satellite images using monoplotting function of Barista software [33, 34] and classified the building height types by ArcGIS software. Then we analyzed the variation characteristic of building height types mainly based on spatial analysis of ArcGIS. The flowchart of the applied methodology in the research as Fig. 2.

\section{Data and Landscape Classification}

Buildings' 3D information was extracted from QuickBird images (2003, 2006, 2009 and 2012) using monoplotting function of Barista software [33, 34], a manual method for 3D information extraction from high resolution satellite images mainly based on Digital Elevation Model (DEM), Ground Control Points (GCPs) detected by GPS and a set of Rational Polynomial Coefficients (RPC) [35] is given as parameters of the Rational Function Model (RFM) for QuickBird images. The monoplotting function solves the planimetric position via least-squares estimation, with the final height being determined via interpolation from the DEM [36]. With the assumption of equal planimetric position, height difference information can be obtained by measuring the visible floor point of the building and then measuring the roof point corresponding to that floor point and the remaining roof boundary points in the same image [36]. Both buildings' frame and height were attained (Fig. 3). The landscape types contain vacant lots (VL, is the ground besides building land in the study area) and buildings. We divided the buildings' 

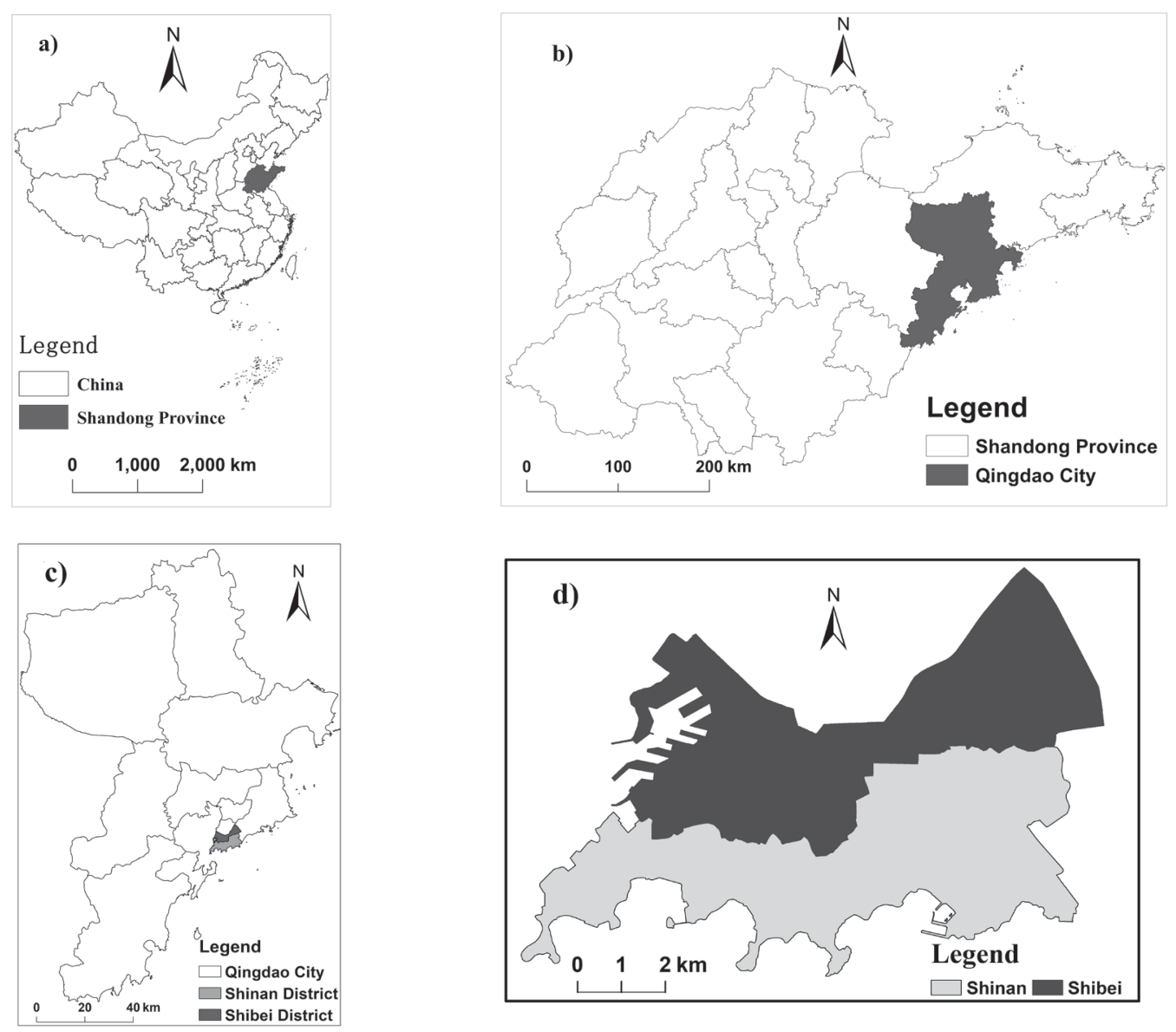

Fig. 1. Location of the study area a) China, b) Shandong Province, c) Qingdao City, d) Shinan and Shibei districts.

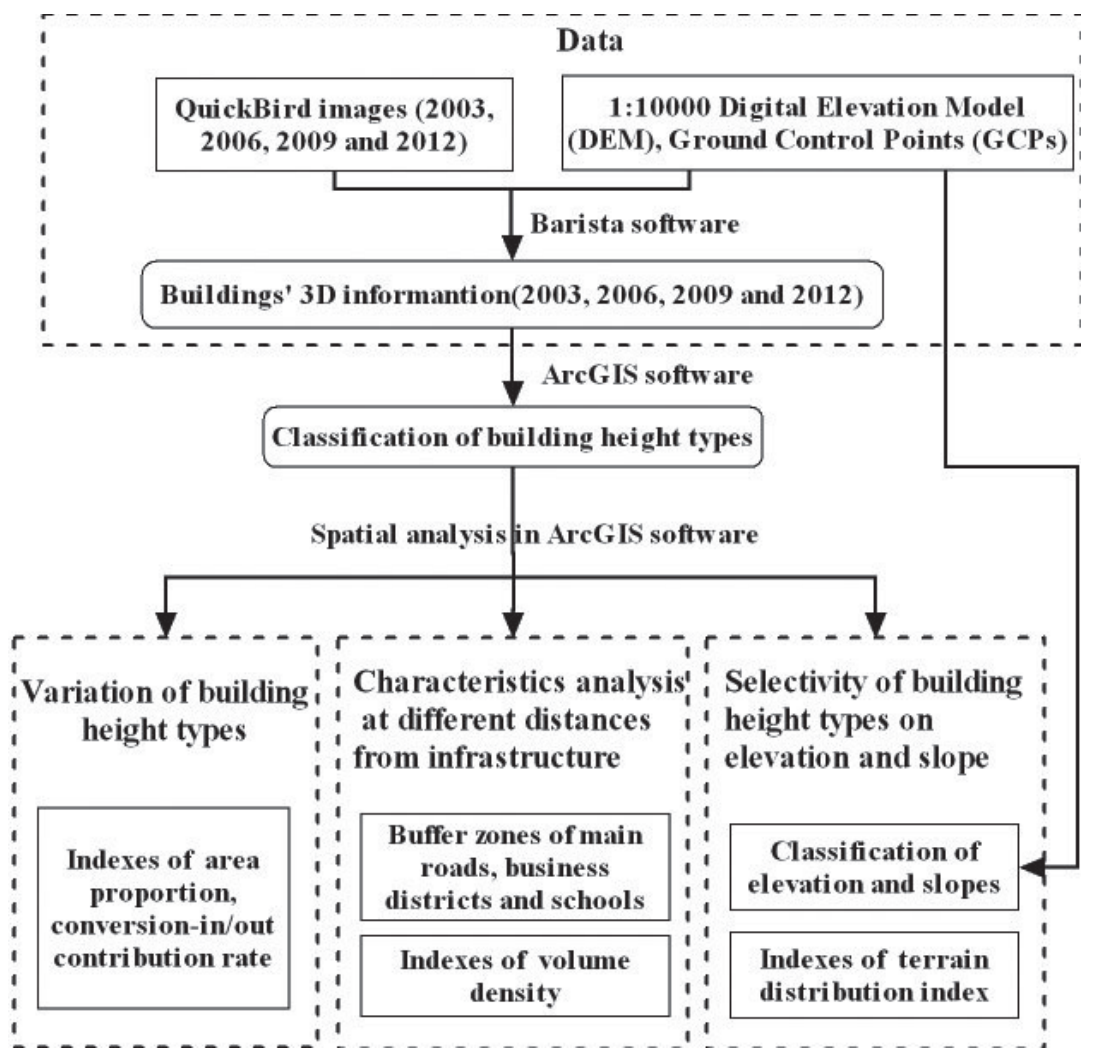

Fig. 2. The flowchart of methodology. 


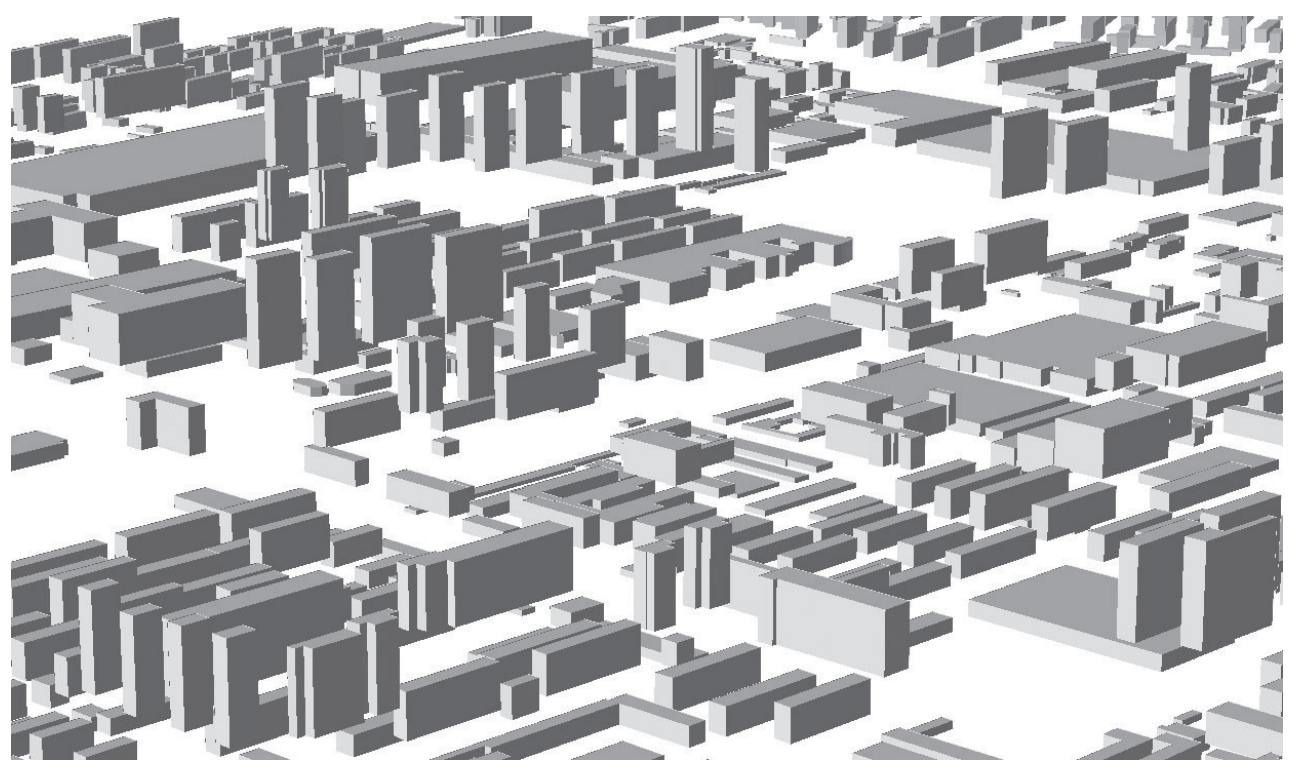

Fig. 3. Buildings' 3D information.

height $(\mathrm{H})$ in the study area into five types [37]: lowrise buildings (LR, $\mathrm{H} \leq 10 \mathrm{~m}$ ), mid-rise buildings (MR, 10m $<\mathrm{H} \leq 19 \mathrm{~m}$ ), mid-high-rise buildings (MHR,
$19 \mathrm{~m}<\mathrm{H} \leq 30 \mathrm{~m}$ ), high-rise buildings ( $\mathrm{HR}, 30 \mathrm{~m}<\mathrm{H} \leq 100 \mathrm{~m})$ and ultra-high-rise buildings (UHR, $\mathrm{H}>100 \mathrm{~m}$ ) using ArcGIS (Fig. 4), according to 'Code for Residential
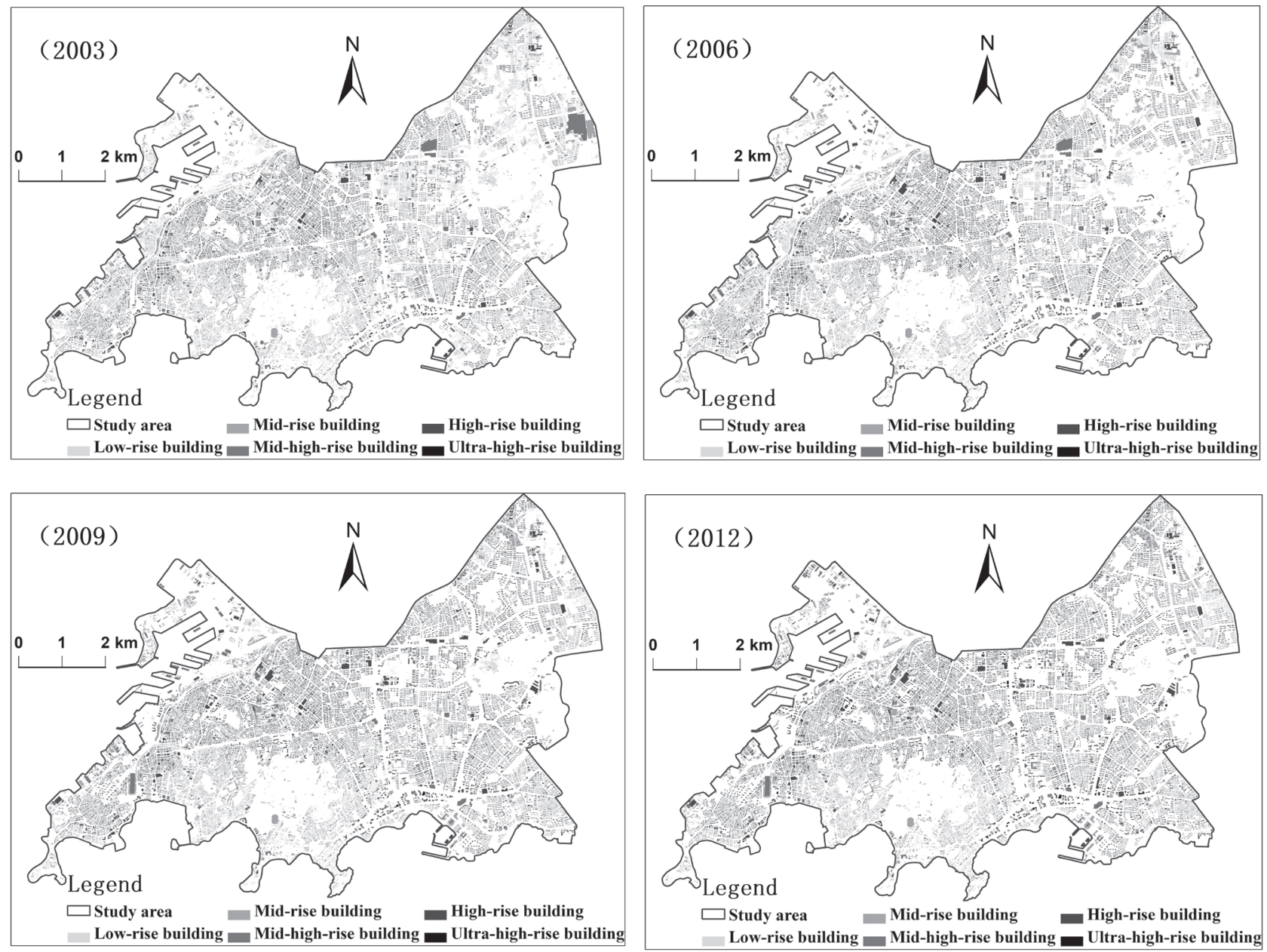

Fig. 4. Classification of building height types. 
Design' [38] and 'General Rules for Civil Building Design' [39] of the People's Republic of China.

\section{Analysis of Building Height Types}

To analyze the spatio-temporal characteristics of building height types in 3D space from 2003 to 2012. We calculated area proportion $\left(\mathrm{AP}_{\mathrm{i}}\right)$ [37], conversion-in contribution rate $\left(\mathrm{TR}_{\mathrm{i}}\right)$ and conversion-out contribution rate $\left(\mathrm{TC}_{\mathrm{i}}\right)$ [40] to reflect the composition and change characteristics of building height types using statistical and spatial overlay analysis of ArcGIS. The $\mathrm{AP}_{\mathrm{i}}, \mathrm{TR}_{\mathrm{i}}$ and $\mathrm{TC}_{\mathrm{i}}$ are obtained through Equation (1) to Equation (3):

$$
\begin{gathered}
A P_{i}=A_{i} / A \\
T R_{i}=\sum_{j=1}^{m} A_{j-i} / A_{t} \\
T C_{i}=\sum_{j=1}^{m} A_{i-j} / A_{t}
\end{gathered}
$$

...where $A_{i}$ is the area of the $i$-th building height type in study area. $\mathrm{A}$ is the total area of the district. $\mathrm{A}_{\mathrm{i}-\mathrm{i}}$ and $A_{i-j}$ are the converted area from the $j$-th/i-th landscape type to the $\mathrm{i}$-th $/ \mathrm{j}$-th type. $\mathrm{A}_{\mathrm{t}}$ is the total area of the landscape transfer. $m$ is the number of landscape types.

\section{Analysis of Building Height Types Based on Infrastructure}

The main roads (national highway, provincial highway and urban arterial roads in the study area) [41], four business districts (Zhongshan Road business district, Taidong Road business district, Central business district and the center district of Qingdao) [32] and schools (Fig. 5) were identified from QuickBird images and urban planning data of Qingdao City [32] in study area.

In order to analyze the variations in volume density of five building height types in different distances from infrastructure, we built 17 buffer-zones at an interval of $100 \mathrm{~m}$ along the main roads, 19 buffer-zones at an interval of $200 \mathrm{~m}$ around the four business districts, and 16 buffer-zones at an interval of $200 \mathrm{~m}$ around the schools (primary and secondary schools in the study area) (Fig. 5), respectively, in ArcGIS. Volume density $\left(\mathrm{VD}_{\mathrm{i}}\right)$ [42] was used to reflect the volume occupied in 3D space by one building height type per unit area in a district. The higher value of $\mathrm{VD}_{i}$ means the $\mathrm{i}$-th building height type was the dominant architectural landscape types in the district. The $\mathrm{VD}_{i}$ is obtained through Equation (4):

$$
V D_{i}=V_{i} / A
$$
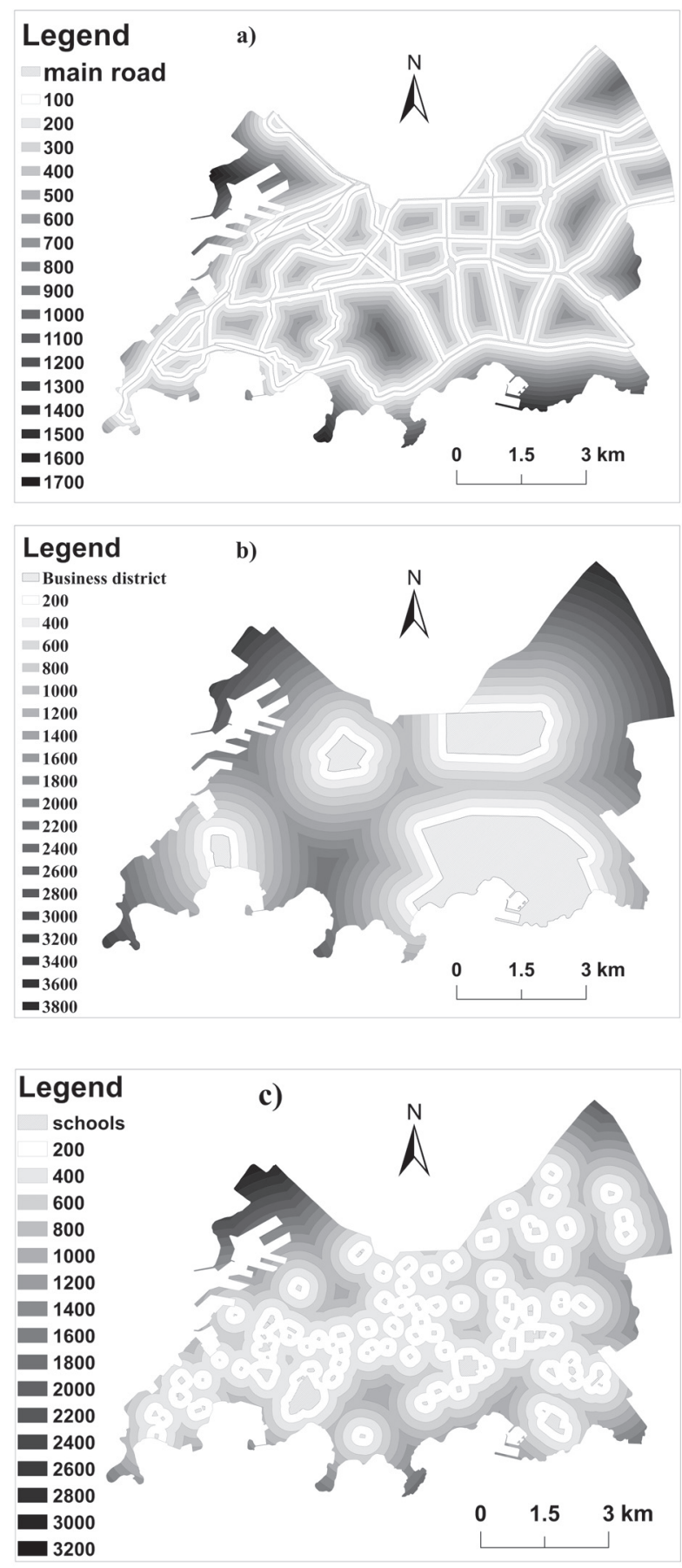

Fig. 5. The buffer zones of main roads, business districts and schools. a) main road, b) business districts, c) schools.

...where $\mathrm{V}_{\mathrm{i}}$ and $\mathrm{A}$ are the volume of the $\mathrm{i}$-th building height type and the total area of the district.

\section{Analysis of Building Height Types Based on Terrain}

More than $86 \%$ of the study area with elevation below $60 \mathrm{~m}$, in order to analyze the spatial distribution characteristics of different building height types in the 
study area, the elevation (E) was divided into: $\mathrm{E} \leq 20 \mathrm{~m}$,

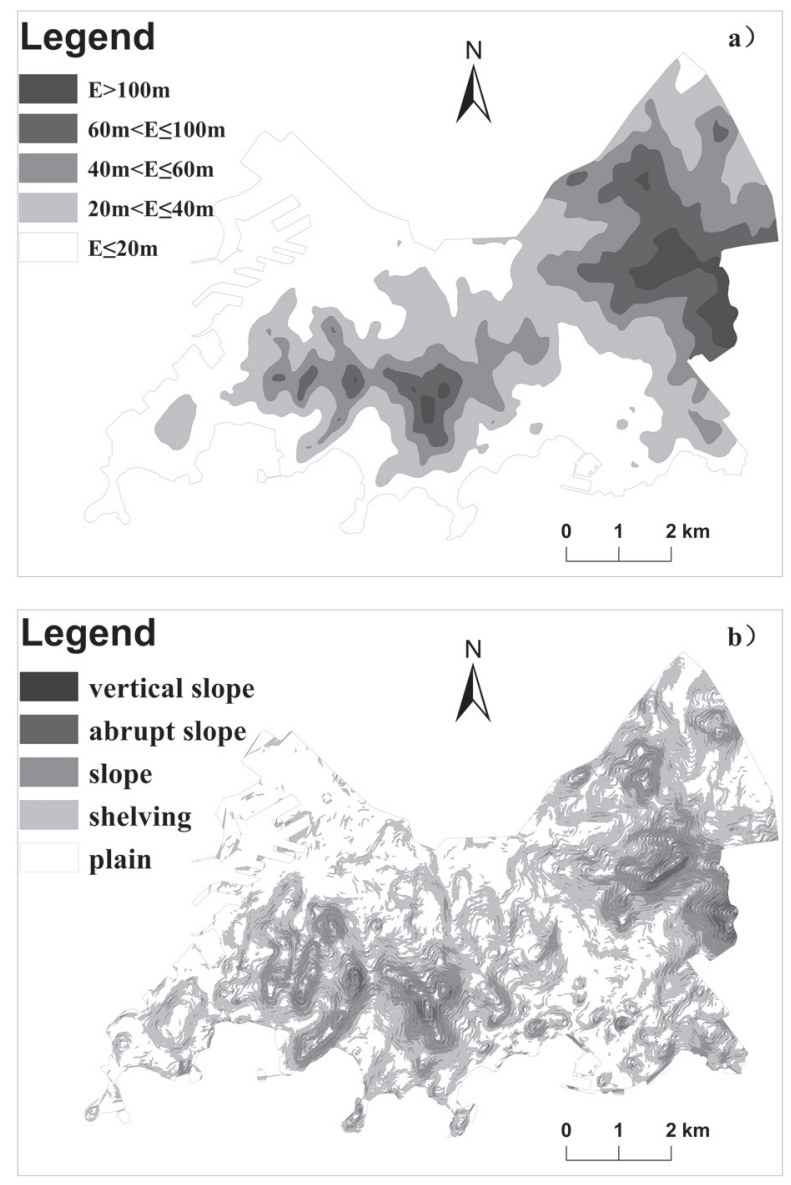

Fig. 6. Classification of a) elevation and b) slope.

$20 \mathrm{~m}<\mathrm{E} \leq 40 \mathrm{~m}, 40 \mathrm{~m}<\mathrm{E} \leq 60 \mathrm{~m}, 60 \mathrm{~m}<\mathrm{E} \leq 100 \mathrm{~m}$ and $\mathrm{E}>100 \mathrm{~m}$. We divided slope $(\mathrm{S})$ into: plain $\left(\mathrm{S}<2^{\circ}\right)$, shelving $\left(2 \leq \mathrm{S}<5^{\circ}\right)$, slope $\left(5^{\circ} \leq \mathrm{S}<15^{\circ}\right)$, abrupt slope $\left(15^{\circ} \leq \mathrm{S}<55^{\circ}\right)$ and vertical slope $\left(\mathrm{S} \geq 55^{\circ}\right)$ [43] base on 1:10000 DEM using ArcGIS (Fig. 6), referenced from the slope classification of the Committee on
Geomorphological Survey and Mapping Council of International Geographical Union, and combined the characteristics of regional terrain and research purposes. Terrain distribution index $\left(\mathrm{DP}_{\mathrm{i}}\right)$ [44] was used to reflect the dominant elevation and slope areas for one building height type. The $\mathrm{DP}_{\mathrm{i}}$ is obtained through Equation (5): We calculated $\mathrm{DP}_{\mathrm{i}}$ of the five building height types on different elevation and slope areas, based on spatial overlay analysis of ArcGIS, from 2003 to 2012.

$$
D P_{i}=\frac{A_{\text {ip }} / A_{i}}{A_{p} / A}
$$

...where $\mathrm{A}_{\mathrm{ip}}$ is area of $\mathrm{i}$-th building type on $\mathrm{p}$-th terrain, $A_{i}$ is the area of the $i$-th building height type in study area, $A_{p}$ is total area of $p$-th terrain, $A$ is the total area of the district. $\mathrm{DP}_{\mathrm{i}}>1$, it means the $\mathrm{p}$-th terrain is the dominant topography for the distribution of $i$-th building type. Higher value of $\mathrm{DP}_{\mathrm{i}}$ means the more dominant topography.

\section{Results and Discussion}

\section{Changes in Building Height Types}

Fig. 7 indicates that MR and MHR buildings were the main architectural landscape components, occupying more than $60 \%$ of the total building area from 2003 to 2012. The area proportion of MR, MHR, HR and UHR buildings increased, but LR buildings decreased. MHR and HR buildings expanded the most rapidly in the study period.

The total conversion area of landscape types decreased. In the first stage (2003-2006) the conversion area was $3.98 \mathrm{~km}^{2}$, in the second stage (2006-2009) it was $3 \mathrm{~km}^{2}$ and in the third stage (2009-2012) it was $1.79 \mathrm{~km}^{2}$. Fig. 8 shows that the conversion-in contribution rate of VL was the highest, covering about $50 \%$ of the total conversion area. MR, MHR and

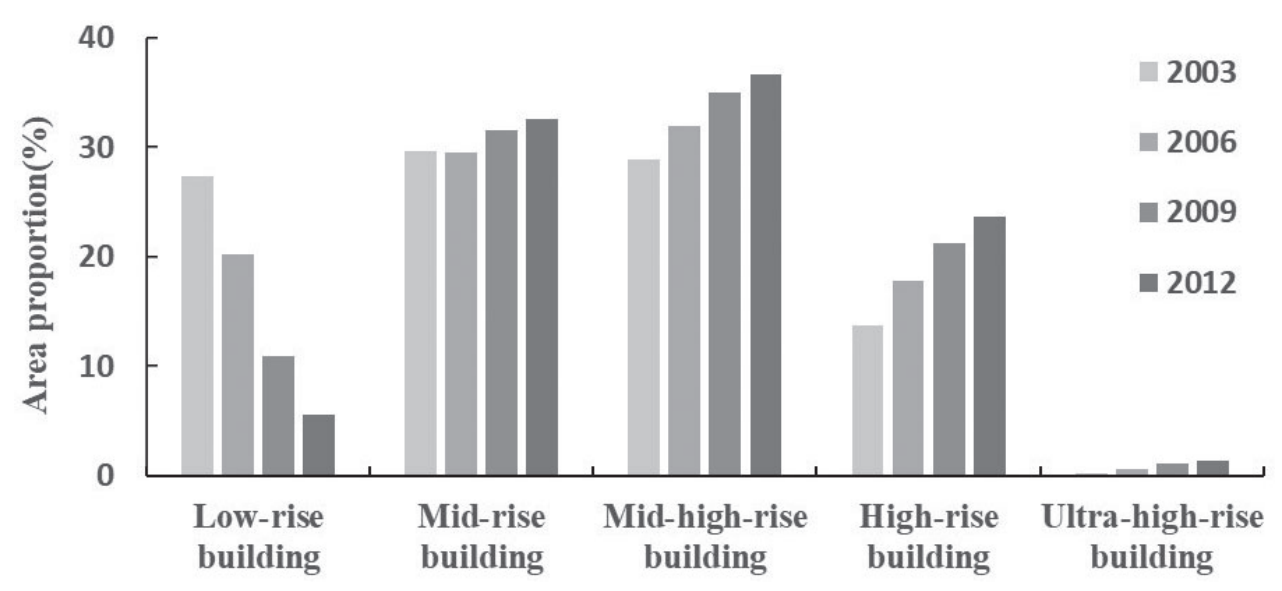

Fig. 7. Area proportion of building height types. 

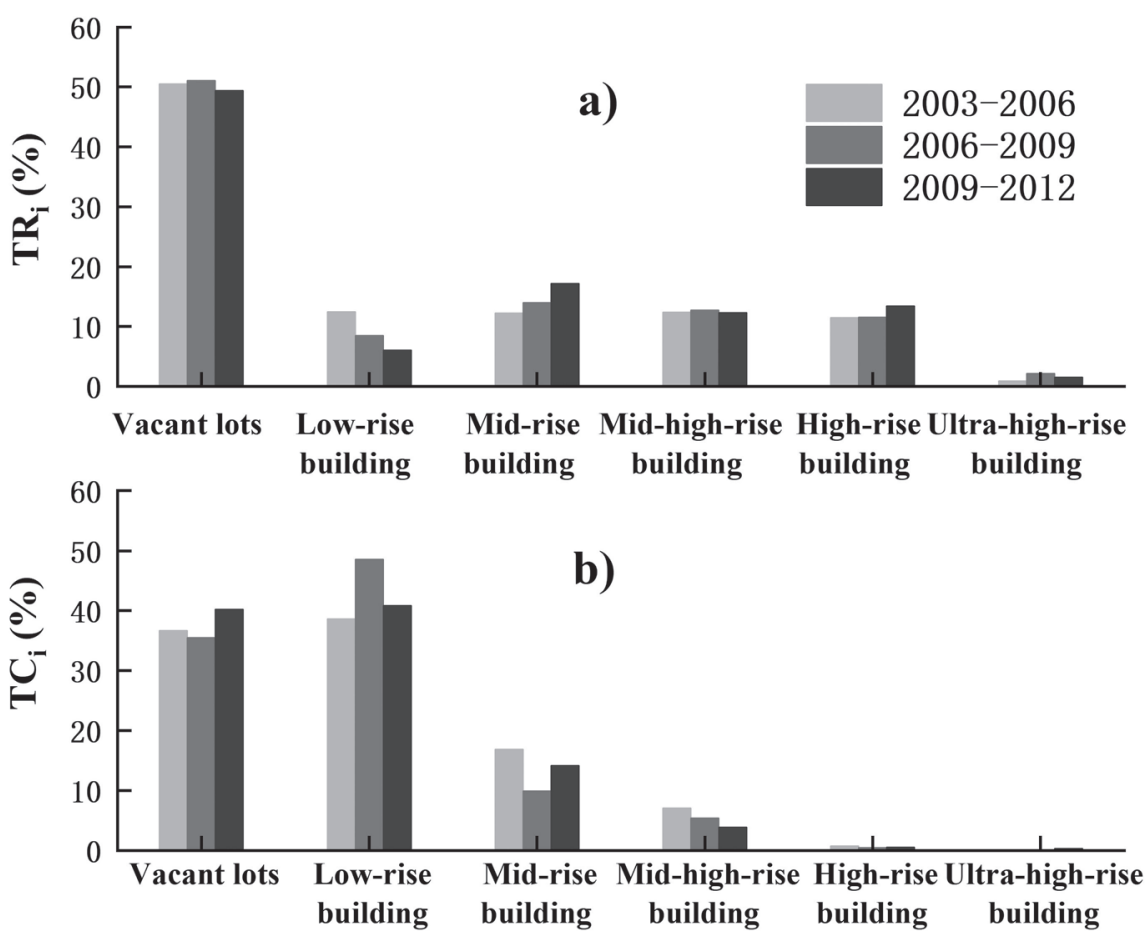

Fig. 8. The conversion contribution rate of landscape types from 2003 to 2012. a) the conversion-in contribution rate, b) the conversionout contribution rate.

HR buildings were found in approximately $12 \%$ of the total conversion areas, respectively. The conversionin contribution rate of building height types increased, except for LR which decreased. The conversion-out contribution rate of LR buildings was the largest in approximately $40 \%$ of the change areas, and the order from high to low was $\mathrm{LR}>\mathrm{MR}>\mathrm{MHR}>\mathrm{HR}>\mathrm{UHR}$ buildings. UHR buildings had the lowest change rate. This result demonstrated that many buildings were demolished, especially LR buildings. MR, MHR and HR buildings were the primary architectural renewal types from 2003 to 2012 . LR buildings were the major landscape types that were replaced by higher buildings and VL, followed by MR buildings, in the urban renewal process. MHR and HR buildings were the dominant renewal landscape types, especially HR buildings that had the highest net conversion-in contribution rate. MR and UHR buildings did not change much, VL increased and LR buildings decreased markedly. It means that buildings expand in vertical direction, building coverage ratio decreases and buildings occupy more volume in 3D space, from 2003 to 2012.

The variation characteristics of building height types are the inevitable result of shantytown reconstruction policy, population increase and economic development in Qingdao city since 2001. Increasing building height and floor area ratio is the effective way to improve the land use efficiency and urban capacity duo to limited land resources and higher requirements of urban development. Low-rise and mid-rise buildings were replaced by mid-high-rise and high-rise buildings, and urban buildings expanded in vertical direction are the remarkable features of China urbanization. This phenomenon was consistent with the urban renewal policy where shanty towns were priority sites for reconstruction. While, this process resulted in a series of urban atmospheric environmental problems [46] as intensifying the urban heat island effect, reducing the urban wind speed, making the pollutants diffusion more difficult, etc.

\section{Characteristics of Building Height Types at Different Distances from Main Roads}

The volume density of MHR, HR and UHR buildings increased, MR buildings showed little change, and LR buildings decreased, at different distances from main roads, from 2003 to 2012 (Fig. 9). (1) Within $700 \mathrm{~m}$ of main roads, the volume density of MHR and HR buildings was the highest, and that of LR and UHR buildings was the lowest. MHR and HR buildings were the main architectural landscape components. The volume density of MHR, HR and UHR buildings decreased rapidly with distance from main roads. (2) Within the distance over $700 \mathrm{~m}$ from main roads, the volume density of all buildings changed fluctuated with distance from main roads, and they grew at different rates from 2003 to 2012. The volume density of MR, MHR and HR buildings was higher and grew faster, UHR buildings grew slightly, LR buildings decreased significantly.

The distribution of building height types varied with different distances from main roads in the process of urbanization. MHR and HR buildings were the primary 

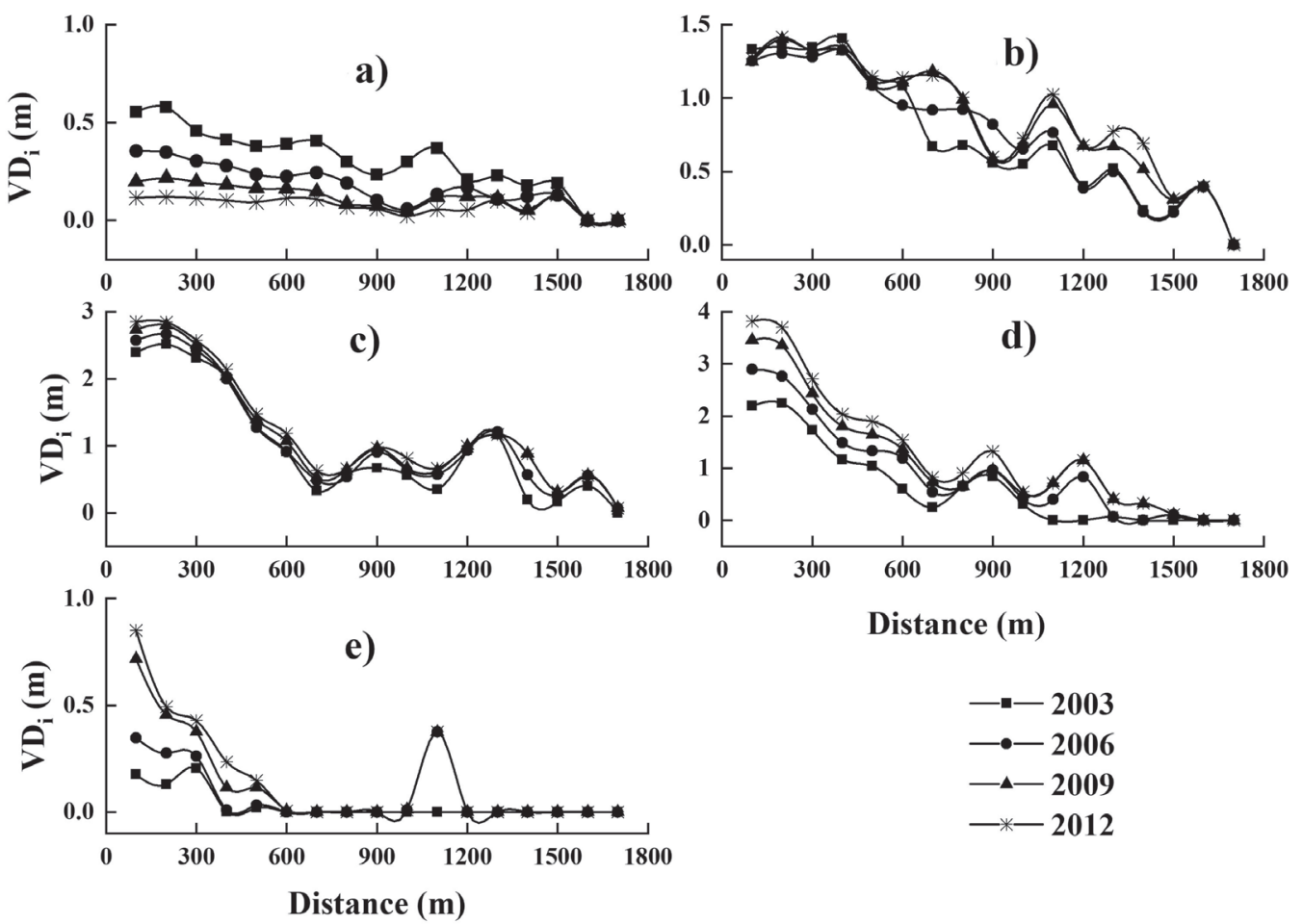

Distance (m)

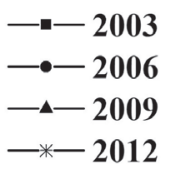

Fig. 9. Volume density of building height types in different distance from main roads. a) Low-rise buildings, b) Mid-rise buildings, c) Mid-high-rise buildings, d) High-rise buildings, e) Ultra-high-rise buildings.

components of the architectural landscape around main roads and increased dramatically from 2003 to 2012. Within $700 \mathrm{~m}$ from main roads, closer to main roads, larger volume was occupied by MHR, HR and UHR buildings per unit area in 3D space, more higher buildings were distributed, and this phenomenon was highlighted during the urban renewal process. The variation of volume density of MHR, HR and UHR buildings indicated that main roads had a significant effect on the spatial layout of building height types within a certain distance.

\section{Variation of Building Height Types Away from Business Districts}

Fig. 10 shows that the volume density of MHR, HR and UHR buildings increased, LR buildings decreased, and MR buildings changed slightly, at different distances from business districts over the study period. (1) Within $1800 \mathrm{~m}$ from business districts, the volume density of MHR, HR and UHR buildings decreased gradually with increasing distance from business districts. MHR and HR buildings had the largest volume density and this grew rapidly from 2003 to 2012 . (2) When the distance was over $1800 \mathrm{~m}$ from business districts, the volume density of all buildings fluctuated with increasing distance.

MR, MHR and HR buildings were the primary components of the architectural landscape around the four business districts and increased dramatically from 2003 to 2012. The distribution of building height types varied at different distances from business districts in the study area. Within $1800 \mathrm{~m}$ from the business districts, the closer to the business districts, the larger volume were occupied by MR, MHR and HR buildings per unit area in $3 \mathrm{D}$ space, more higher buildings were distributed. The variation of volume density of MR, MHR and HR buildings indicated that business districts had a significant radiation effect on the spatial layout of building height types within a certain distance.

\section{Distinction of Building Height Types Around Schools}

The volume density of MR, MHR, HR and UHR buildings increased, that of LR buildings decreased over the study period (Fig. 11). The volume density of MHR and HR buildings was the largest, and that of LR and UHR buildings was the smallest around schools. (1) When the distance was less than $1000 \mathrm{~m}$ from schools, the volume density of all buildings decreased gradually with greater distances from schools, especially of MHR and HR buildings. (2) When the distance was over $1000 \mathrm{~m}$ away from schools, the volume density of all buildings showed a fluctuating trend with greater distance from schools. This indicated that the distribution of building height types showed a clear difference at various distances away from schools in the study area. MHR and HR buildings were the primary components of the architectural landscape around schools, and increased dramatically from 2003 to 2012. Within $1000 \mathrm{~m}$ from schools, the closer to schools, the 

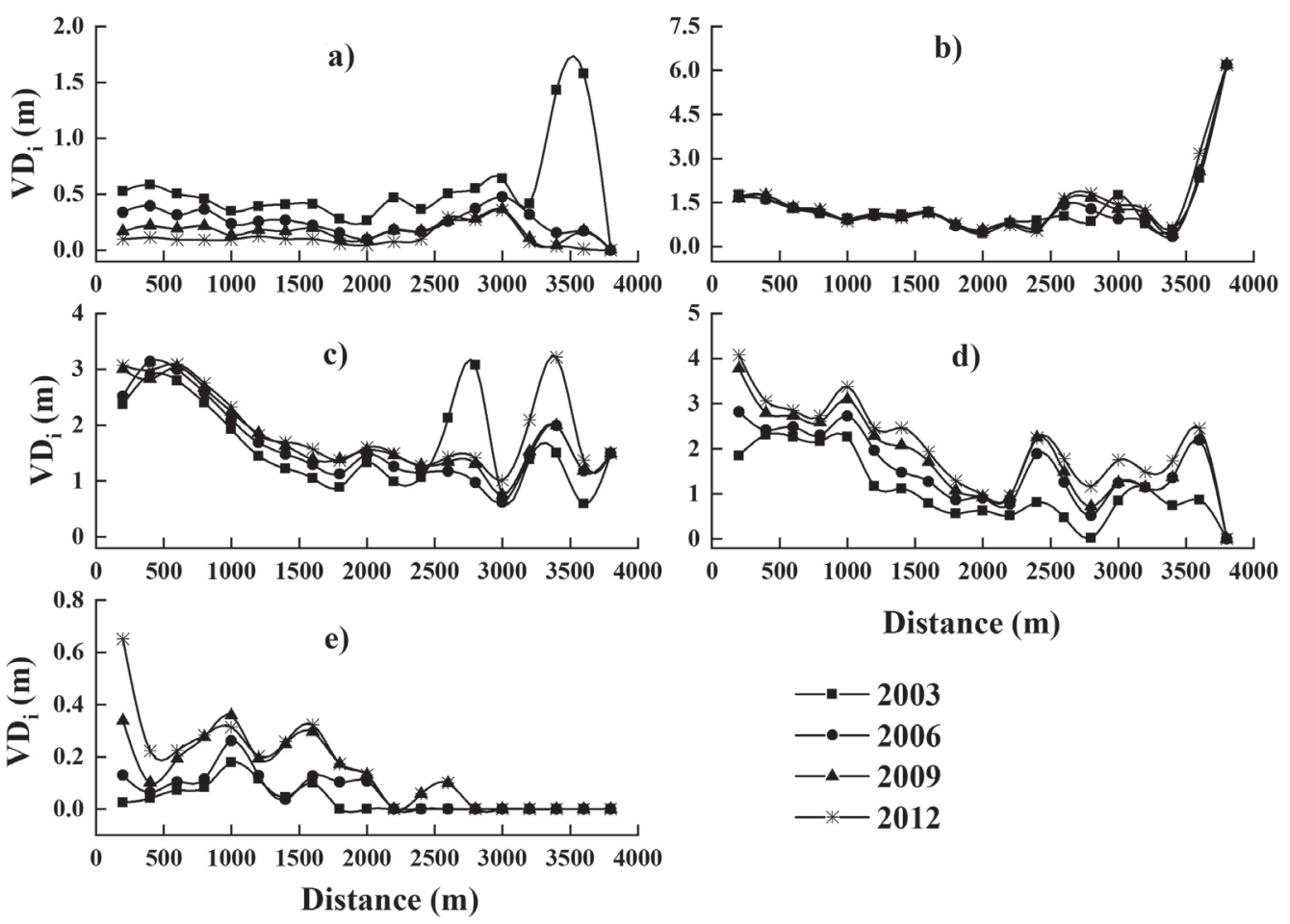

Distance (m)

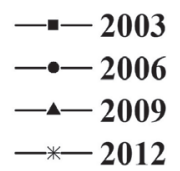

Fig. 10. Volume density of building height types in distance from business districts. a) Low-rise buildings, b) Mid-rise buildings, c) Midhigh-rise buildings, d) High-rise buildings, e) Ultra-high-rise buildings.

larger volume were occupied by MHR and HR buildings per unit area in 3D space, more higher buildings were distributed. The volume density variation of MHR and
HR buildings indicated that schools had a significant radiation effect on the spatial layout of building height types within a certain distance.
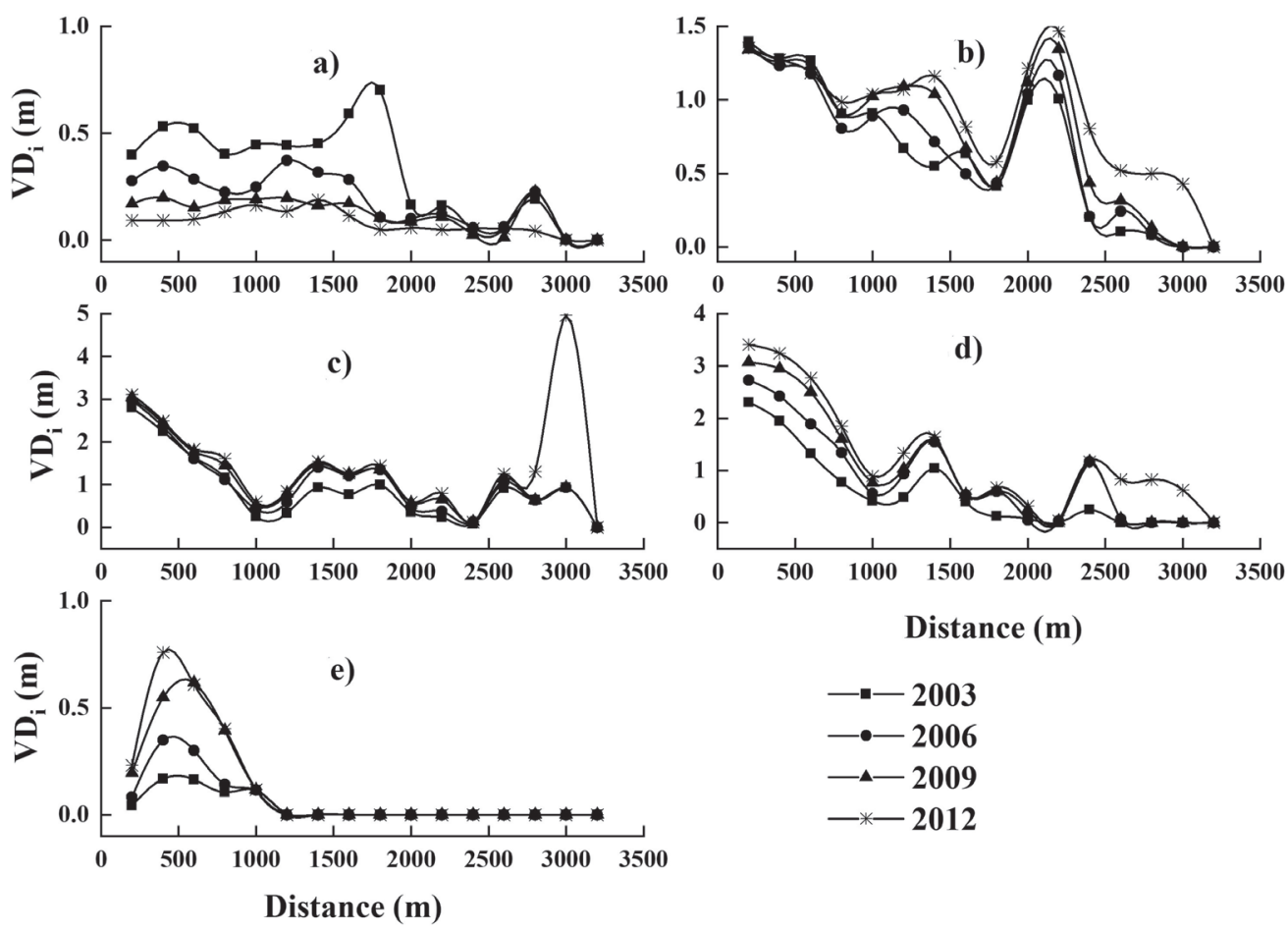

Distance (m)

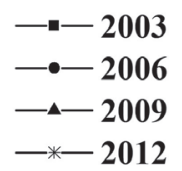

Distance (m)

Fig. 11. Volume density of building height types in different distance from schools. a) Low-rise buildings, b) Mid-rise buildings, c) Midhigh-rise buildings, d) High-rise buildings, e) Ultra-high-rise buildings. 
Main roads, business districts and schools have strong radiation and driving effect on the spatial distribution of urban population and economy. The closer to main roads [11, 12], business districts [18] and schools [17], the faster of economic development, greater population and economic density, higher land price and land use intensity, and greater social and economic benefits that all resulted in higher building height and floor area ratio. The radiative driving effect of public facilities on the architectural landscape was weakened when the distance was increased. However, the impact range on the surrounding architectural landscape is different due to the functional differences of main roads, business districts and schools. With the urban development, the mid-high-rise and highrise buildings increased, the population and economy became more intensive, the land use efficiency was improved significantly, yearly, around main roads, commercial districts and schools. Our results were consistent with conclusions from previous studies, namely that: the urbanization-related fragmentation of landscapes decreased with distance from roads [16], a location with the advantage of road centrality attracted more commercial, financial and residential interest [47], and the urban growth form generally showed exponential attenuation with increasing distance to roads [12]. The location, scale, and grade of urban public facilities determined the spatial attraction of the urban architectural landscape. As a result, congested traffic, complex wind-heat environment in the streets are, and poor atmospheric environmental quality in local areas.
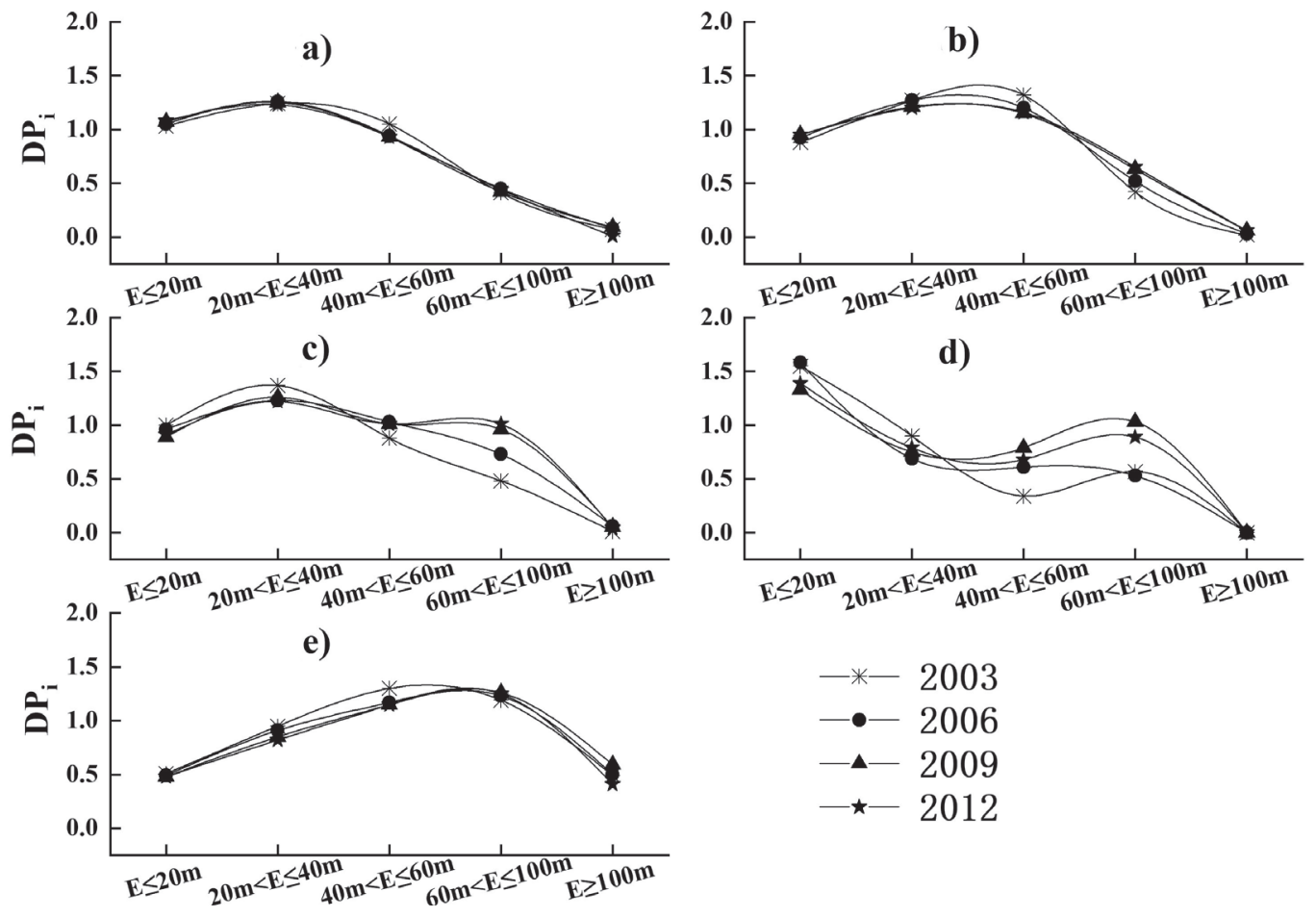

Fig. 12 shows that from 2003 to 2012 the dominant topography for LR, MR, MHR, HR and UHR buildings was below $40 \mathrm{~m}, 20-60 \mathrm{~m}, 20-40 \mathrm{~m}$, lower than $20 \mathrm{~m}$ and $40-100 \mathrm{~m}$ of elevation, respectively. The terrain distribution index of LR, MR and MHR decreased rapidly with the increasing elevation, and that of HR buildings decreased with the increasing elevation except 60-100 m. However, the terrain distribution index of UHR buildings increased with the increasing elevation and attained the maximum value on $60-100 \mathrm{~m}$ of elevation, then decreased. Generally, the dominant topography for buildings was the area below $60 \mathrm{~m}$ of elevation, and the terrain distribution index of all buildings decreased except UHR buildings increased with greater elevation. From 2003 to 2012, the terrain distribution index of LR, MR and UHR buildings decreased yearly on 40-60 m of elevation and changes little on lower than $40 \mathrm{~m}$ and $60-100 \mathrm{~m}$ of elevation, and that of MHR and HR buildings decreased yearly on lower than $40 \mathrm{~m}$ and increased yearly on $40-100 \mathrm{~m}$ of elevation, while that of all buildings close to zero and no changes on higher than $100 \mathrm{~m}$ of elevation.

The dominant slope for all buildings were the plains and shelving where the slope was less than $5^{\circ}$ (Fig. 13). In the study area, the terrain distribution index of all buildings decreased gradually with the increasing slope, slightly changed in plain, shelving, slope and abrupt slope zones, and close to zero and no changes in vertical

Fig. 12. Terrain distribution index of building height types on elevation. a) Low-rise buildings, b) Mid-rise buildings, c) Mid-high-rise buildings, d) High-rise buildings, e) Ultra-high-rise buildings. 

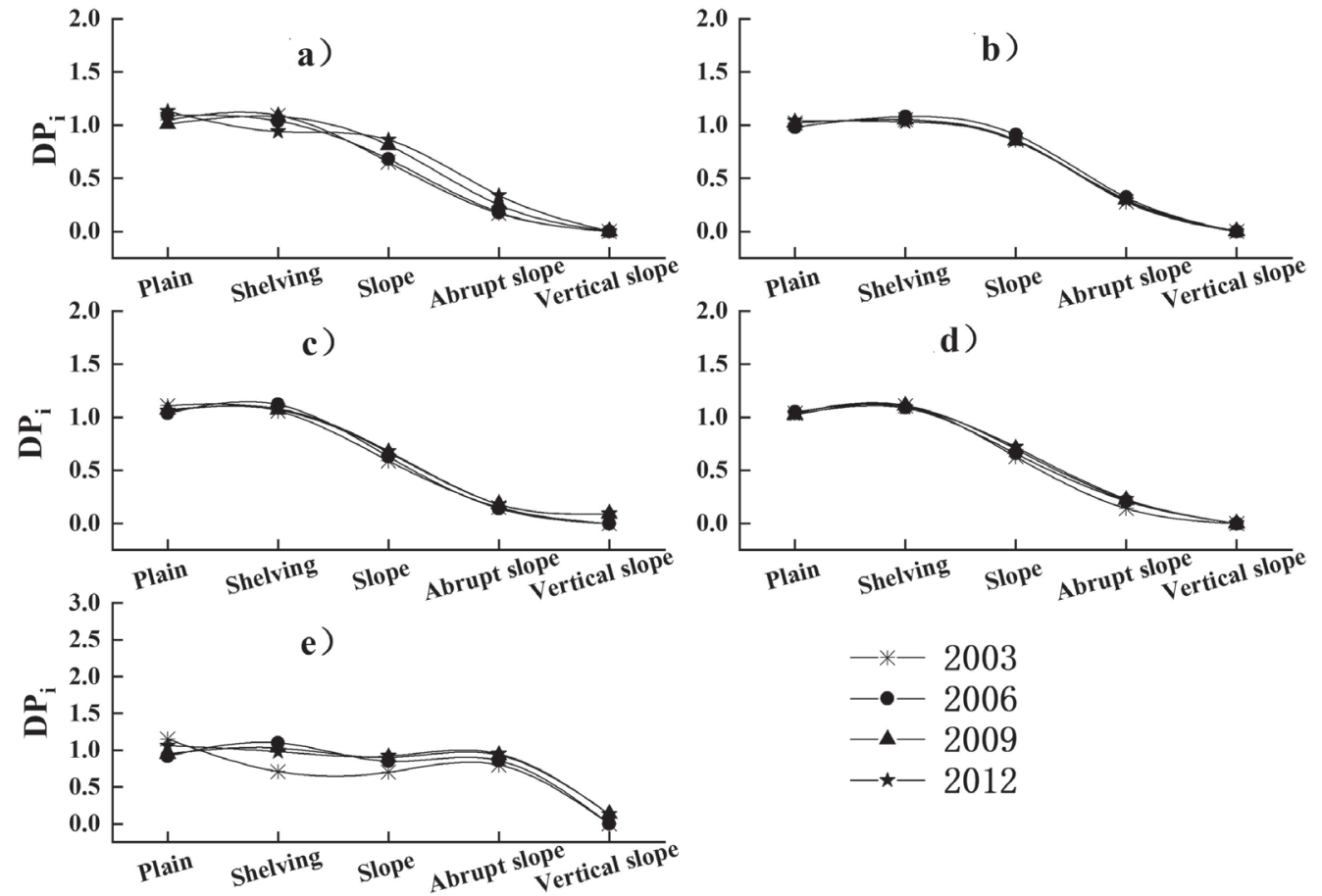

Fig. 13. Terrain distribution index of building height types on slope. a) Low-rise buildings, b) Mid-rise buildings, c) Mid-high-rise buildings, d) High-rise buildings, e) Ultra-high-rise buildings.

slope area, from 2003 to 2012. In the slope and abrupt slope area, the terrain distribution index of LR, MHR, HR and UHR buildings increased yearly from 2003 to 2012.

The results demonstrated that buildings were mainly distributed in the area below $60 \mathrm{~m}$ of elevation, in plains and shelving areas with slope less than $5^{\circ}$, and the greater elevation and higher slope areas became the dominate terrain for MHR, HR and UHR buildings, gradually, over the study period due to the development of the social economy and technology from 2003 to 2012 .

Terrain (elevation and slope) has a strong influence on the distribution of building height types during the urban development process. The area with low elevation and gentle slope has become the best choice for urban building because of its easy to develop and low cost [24, 25 ]. Then buildings are gradually distributed in areas with high elevation and large slope with the shortage of land resources and technology development during the urban development process. In this paper, the study area was mainly with plain and lower elevation. however, the spatio-temporal evolution characteristics of buildings on the terrain from 2003-2012 in urbanization process fully conform to the spatial distribution law of urban buildings on the terrain.

Although our study on the spatio-temporal characteristics of building height types in 3D space around urban public facilities and terrain had some limitations, such as the research area was not large enough $\left(58.64 \mathrm{~km}^{2}\right)$ and the structure of terrain was simple, the data was mainly attained from high- resolution satellite images (QuickBird, spatial resolution is $61 \mathrm{~cm}$ ) with $91.8 \%$ of building height accuracy [48] and enough for our research. The results reflect the common spatio-temporal characteristics of building height types in most cities in China. Our results are important for understanding the characteristics of architecture landscape, simulating the evolution of urban architectural landscape and researching the urban atmospheric environment.

\section{Conclusions}

In this study, we mainly detected the spatio-temporal variation characteristics of building height types based on buildings' 3D information attained from highresolution satellite images (QuickBird) using spatial analysis in ArcGIS software. We found that lower (LR and MR) buildings were gradually replaced by vacant lots and higher (MHR, HR and UHR) buildings. Building height increased gradually and the urban area grew in a vertical direction from 2003 to 2012 in study area. The infrastructures (main roads, business districts and schools) and terrain had obvious influence on the distribution of building height types. Areas closer to main roads, business districts and schools had larger volume density of MR, MHR and HR buildings within the range of $700 \mathrm{~m}, 1800 \mathrm{~m}$ and $1000 \mathrm{~m}$ distance from these infrastructures. Most buildings were located in the zones with elevation below $60 \mathrm{~m}$ and slope less than $5^{\circ}$. The higher elevation and larger slope areas were developed for building construction gradually. 
This study fills the gaps in the study of the evolution characteristics of building height types of urbanization process in China, and will provide important guidance for urban planning, urban environmental governance and ecological city construction.

In the future, high resolution satellite images (QuickBird, WorldView, ALOS, GeoEye, and LIDAR, etc.) and semi-automatic extraction method (Barista or ArcGIS software) should be used to attain the buildings' 3D information in a city. Spatial analysis methods (spatial overlay, spatial buffering, etc.) of ArcGIS will be the efficient method for spatio-temporal variation analysis of building height types and related research in the urbanization process. Both the data acquisition and analysis method will be useful for urban planning, urban evolution and urban environment, etc.

\section{Acknowledgments}

Funding for this project was provided by the Key Project of the Shandong Provincial Natural Science Foundation (No. ZR2018QD001), Fundamental Research Funds for the Central Universities (No. 18CX02078A) and National Natural Science Foundation of China (No. 41301198).

\section{Conflict of Interest}

The authors declare no conflict of interest.

\section{References}

1. AGUILERA F., VALENZUELA L.M., BOTEQUILHALEITAO A. Landscape metrics in the analysis of urban land use patterns: A case study in a Spanish metropolitan area. Landscape and Urban Planning, 99 (3-4), 226, 2011.

2. HAREGEWEYN N., FIKADU G., TSUNEKAWA A., TSUBO M., MESHESHA D.T. The dynamics of urban expansion and its impacts on land use/land cover change and small-scale farmers living near the urban fringe: A case study of Bahir Dar, Ethiopia. Landscape and Urban Planning, 106 (2), 149, 2012.

3. JIANG L., DENG X., SETO K.C. Multi-level modeling of urban expansion and cultivated land conversion for urban hotspot counties in China. Landscape and Urban Planning, 108 (2-4), 131, 2012.

4. CHEN J., CHANG K.T., KARACSONYI D., ZHANG X. Comparing urban land expansion and its driving factors in Shenzhen and Dongguan, China. Habitat International, 43 (0), 61, 2014.

5. XU X., MIN X. Quantifying spatiotemporal patterns of urban expansion in China using remote sensing data. Cities, 35 (0), 104, 2013.

6. NASSAR A.K., ALAN BLACKBURN G., DUNCAN WHYATT J. Developing the desert: The pace and process of urban growth in Dubai. Computers, Environment and Urban Systems, 45 (0), 50, 2014.

7. LI Y., ZHU X., SUN X., WANG F. Landscape effects of environmental impact on bay-area wetlands under rapid urban expansion and development policy: A case study of Lianyungang, China. Landscape and Urban Planning, 94 (3-4), 218, 2010.

8. LIU Z., HE C., ZHANG Q., HUANG Q., YANG Y. Extracting the dynamics of urban expansion in China using DMSP-OLS nighttime light data from 1992 to 2008. Landscape and Urban Planning, 106 (1), 62, 2012.

9. LI L., SATO Y., ZHU H.H. Simulating spatial urban expansion based on a physical process. Landscape and Urban Planning, 64 (1-2), 67, 2003.

10. TIAN J., YU M., REN C., LEI Y. Network-scape metric analysis: a new approach for the pattern analysis of urban road networks. International Journal of Geographical Information Science, 33 (3), 537, 2019.

11. XIE Y., GONG J., SUN P., GOU X., XIE Y. Impacts of major vehicular roads on urban landscape and urban growth in an arid region: A case study of Jiuquan city in Gansu Province, China. Journal of Arid Environments, 127, 235, 2016.

12. XU C., FANG S., LONG N., TENG S., ZHANG M., LIU M. Spatial Patterns of Distinct Urban Growth Forms in Relation to Roads and Pregrowth Urban Areas: Case of the Nanjing Metropolitan Region in China. Journal of Urban Planning and Development, 141 (1), 2015.

13. YANG X., WANG L., WU T., QIU Q. Ecological risk assessment based on road network development analysis of Xiamen city, China. International Journal of Sustainable Development and World Ecology, 25 (5), 458, 2018.

14. AZHDARI A., SOLTANI A., ALIDADI M. Urban morphology and landscape structure effect on land surface temperature: Evidence from Shiraz, a semi-arid city. Sustainable Cities and Society, 41, 853, 2018.

15. OU J., LIU X., LI X., CHEN Y., LI J. Quantifying Spatiotemporal Dynamics of Urban Growth Modes in Metropolitan Cities of China: Beijing, Shanghai, Tianjin, and Guangzhou. Journal of Urban Planning and Development, 143 (1), 2017.

16. REIMETS R., UUEMAA E., OJA T., SISAS E., MANDER U. Urbanisation-related Landscape Change in Space and Time along Spatial Gradients near Roads: A Case Study from Estonia. Landscape Research, 40 (2), 192, 2015.

17. SUBASINGHE S., ESTOQUE R.C., MURAYAMA Y. Spatiotemporal Analysis of Urban Growth Using GIS and Remote Sensing: A Case Study of the Colombo Metropolitan Area, Sri Lanka. Isprs International Journal of Geo-Information, 5 (11), 2016.

18. PENG B., SHI Y., SHAN Y., CHEN D. The Spatial Impacts of Class 3A Comprehensive Hospitals on Peripheral Residential Property Prices in Shanghai. Scientia Geographica Sinica, 35 (7), 860, 2015.

19. WU J., WANG M., LI W., PENG J., HUANG L. Impact of Urban Green Space on Residential Housing Prices: Case Study in Shenzhen. Journal of Urban Planning and Development, 141 (4), 2015.

20. MOHAJERI N., GUDMUNDSSON A. Street networks in relation to landforms: Implications for fast-growing cities. Journal of Geographical Sciences, 24 (2), 363, 2014.

21. ZHANG X., BAI Z., FAN X., LU Y., CAO Y., ZHAO Z., SUN Q., PAN J. Urban Expansion Process, Pattern, and Land Use Response in an Urban Mining Composited Zonefrom1986to2013. Journal of Urban Planning and Development, 142 (4), 2016.

22. LIU Q.P., TIAN H.Z., YANG Y.C. Quantitative Study of the Relationship Between the Distribution of Cities and the Natural Environment Based on GIS and RS 
in China. Scientia Geographica Sinica, 32 (6), 686, 2012 [In Chinese].

23. CHEN L.D., SUN R.H., LIU H.L. Eco-environmental effects of urban landscape pattern changes: progresses, problems, and perspectives. Acta Ecologica Sinica, (04), 1042, 2013 [In Chinese].

24. SUN G.Y., WANG C.S., XIAO L., DONG G.P. Rural Residential Land Use Change and Its Influencing Factors in the Rapid-Urbanization Region: A Case Study of Longgang District. Shenzhen. Progress in Geography, 3 (3), 352, 2011 [In Chinese].

25. Li Y.Q., Qi W., Wang D., YAN Y., LU C., WANG N.N., QIN T.T. Research on Spatial Distribution Characteristics of Rural Settlements in Mountainous Areas at County Level Based on GIS:A Case Study in Qixia City. Geography and Geo-Information Science, 27 (3), 73, 2011 [In Chinese].

26. LIN J., HUANG B., CHEN M., HUANG Z. Modeling urban vertical growth using cellular automata-Guangzhou as a case study. Applied Geography, 53, 172, 2014.

27. MAHTTA R., MAHENDRA A., SETO K.C. Building up or spreading out? Typologies of urban growth across 478 cities of 1 million+. Environmental Research Letters, 14 (12), 2019.

28. ZHANG W., LI W., ZHANG C., HANINK D.M., LIU Y., ZHAI R. Analyzing horizontal and vertical urban expansions in three East Asian megacities with the SScoMCRF model. Landscape and Urban Planning, 177, 114, 2018.

29. ZHANG W., LI W., ZHANG C., OUIMET W.B. Detecting horizontal and vertical urban growth from medium resolution imagery and its relationships with major socioeconomic factors. International Journal of Remote Sensing, 38 (12), 3704, 2017.

30. CPC Qingdao Municipal Party History Research Institute. Qingdao Local Chronicles Research Institute, editoreditors. District and city annals, 2020 [In Chinese].

31. Qingdao Statistical Bureau. Qingdao Statistical Yearbook in 2013. 2013 [In Chinese].

32. Qingdao Urban Planning Bureau. Regulatory detailed planning. 2018 [In Chinese].

33. FRASER C., ROTTENSTEINER F., WILLNEFF J., WESER T.Barista User Manual, 2008.

34. BARISTA. Barista product information webpage.http:// www.baristasoftware.com.au. 2008

35. FRASER C.S., ROTTENSTEINER F., WESER T., WILLNEFF J. Application of a generic sensor orientation model to spot 5, quickbird and alos imagery. Asia Conference and Remote SensingKuala Lumpur, 1-7, 2007.

36. WILLNEFF J., POON J., FRASER C. Single-image highresolution satellite data for $3 \mathrm{D}$ information extraction.
International Archives of Photogrammetry, Remote Sensing and Spatial Information Sciences, 36 (1/W3), 2005.

37. ZHANG P.F., HU Y.M., XIONG Z.P., LIU M. A gradient analysis of urban architecture landscape pattern based on QuickBird imagery. Acta Ecologica Sinica, 31 (23), 7251, 2011 [In Chinese].

38. Ministry of Construction of the People's Republic of China. National Standard of the People's Republic of China Code for Design of Residential Buildings GB50096 - 1999 (2003 Edition) Section 1.0.3. 2003 [In Chinese].

39. Urban and Rural Construction and Environmental Protection, PRC. Standard of the Ministry of Urban and Rural Construction and Environmental Protection of the People's Republic of China -General Rules for Civil Building Design JGJ37-87 No.1.0.5. China, 1987 [In Chinese].

40. ZHANG P.F., HU Y.M., XIONG Z.P., LIU M. Evolution law of architectural landscape during the urban renewal process in Tiexi District. Acta Ecologica Sinica, 32 (9), 2681, 2012 [In Chinese].

41. Qingdao Urban Planning Bureau. Road Network Planning of Qingdao City. Planning Road Network Grade Structure Diagram, 2018 [In Chinese].

42. CAO Q., LUAN Q., LIU Y., WANG R. The effects of 2D and 3D building morphology on urban environments: A multi-scale analysis in the Beijing metropolitan region. Building and Environment, 192, 1, 2021.

43. LI F.Y., HE X.W., ZHOU C.H. Advances in Researches on Slope Gradient Factor in Soil Erosion. Research of Soil and Water Conservation, 06, 229, 2008 [In Chinese].

44. CHEN L.D., YANG S., FENG X.M. Land use change characteristics along the terrain gradient and the spatial expanding analysis. A case study of Haidian District and Yanqing County, Beijing. Geographical, Research, 06), 1225-1234+1481, 2008 [In Chinese].

45. ZHANG P., HU Y., XIONG Z. Extraction of ThreeDimensional Architectural Data from QuickBird Images. Journal of the Indian Society of Remote Sensing, 42 (2), 409, 2014.

46. ZHANG P.F., LIU J., GAO Y.J., CHENG Z., QI X.L.,LI $X$. Spatiotemporal variation of wind speed in Shibei District of Qingdao from 2003 to 2018. Chinese Journal of Ecology, 40 (05), 1440, 2021 [In Chinese].

47. YIN C., LIU Y., WEI X., CHEN W. Road Centrality and Urban Landscape Patterns in Wuhan City, China. Journal of Urban Planning and Development, 144 (2), 1, 2018.

48. ZHANG P. Spatiotemporal Features of the ThreeDimensional Architectural Landscape in Qingdao, China. Plos one, 10 (9), 1, 2015. 
